\title{
Pengaruh Industri Pariwisata Terhadap PDRB Kota Padang
}

\author{
Oleh \\ Yenni Del Rosa, Mohammad Abdilla \\ Fakultas Ekonomi dan Bisnis Universitas Dharma Andalas Padang \\ yennidelrosa01@gmail.com
}

\begin{abstract}
Abstrak
The contribution of tourism industry fluctuates to PDRB of Padang city in 2013 - 2017 as well as the number of tourists. The hotel rates are relatively high and the prices of food and beverages sold still do not have a standard price. The above will certainly have PDRB Padang city. The purpose of research to determine the influence of the number of tourists, number of hotels and the number of restaurants to PDRB. Padang city partially and simultaneously. type of research is quantitative, data collection using survey method. The study used time series data analyzed by multiple linear regression technique. Equation of data analysis obtained $\operatorname{Ln} Y=3.418+0.058 \operatorname{Ln} X 1+0.103 \operatorname{Ln} X 2+0.258 \operatorname{Ln} X 3+e$. After hypothesis testing at 5\% significance level, the number of tourists, number of hotel and number of restaurant have significant positive effect to PDRB of Padang city partially and simultaneously because (3.317> 2.021) and (2.134>2.021) and 93.168>2.021) and (5.889> 2.61). The number of hotels and number of restaurants with PDRB of Padang city strong (0.749) and value of Adjusted $R$ Square $=0.602$ means the PDRB of Padang is explained by the number of tourists, the number of hotels and the number of restaurants is $60.2 \%$ while the remaining $39.8 \%$ is explained by other variables not included in the research model.

Keywords: Gross Domestic Product, tourist, hotel, restaurant
\end{abstract}

\section{I . PENDAHULUAN}

\section{A . Latar Belakang Masalah}

Industri pariwisata perkembangannya setiap tahun cukup pesat di Indonesia karena Indonesia terkenal dengan berbagai pesona aneka keindahan alam dan keanekaragaman budaya sehingga jumlah wisatawan mancanegara dan domestik yang berkunjung terus mengalamai peningkatan. Menurut (United Nations World Tourism Organization, 2013) selama enam dekade terakhir, pariwisata telah mengalami pertumbuhan dan diversifikasi sebagai salah satu sektor ekonomi terbesar dan tercepat tumbuh di dunia World Travel and Tourism Council (WTTC) yang memberikan kontribusi sekitar 9,2\% dari Produk Domestik Bruto (PDB) dan hal ini diperkirakan akan terus berkembang lebih dari $4 \%$ per tahun selama selama 10 tahun ke depan (WTTC, 2010). Beberapa keuntungan pariwisata dalam ekonomi menurut (Antari, 2013) adalah sbb: memberikan kontribusi dalam devisa negara, menambah pendapatan masyarakat, menciptakan lapangan kerja, meningkatkan sektor ekonomi, membuka peluang investasi, mendorong aktivitas wirausaha dan berpotensi mendorong penerimaan negara dari pajak tidak langsung.

Pengaruh pariwisata terhadap Produk Domestik Bruto (PDRB) terlihat dari kontribusi jasa pariwisata, penerimaan dan sektor pendukungnya. Sektor 
Jurnal Manajemen dan Kewirausahaan, Volume 9, Nomor 3, September 2018

ISSN: $2086-5031$

E-ISSN 2615-3300

DOI 10.31317

pariwisata merupakan sektor berbasis (Affandi, 2012). Pada tabel 1 berikut ini jasa sebagai salah satu sektor unggulan strategis dalam pembangunan nasional karena mampu mendatangkan devisa dapat dilihat data perkembangan PDRB sektor pariwisata kota Padang tahun 2013 $-2017$.

negara nomor dua setelah minyak dan gas

Tabel 1.

Perkembangan PDRB-ADHB Sektor Pariwisata Kota Padang (Dalam Trilyun Rupiah)

\begin{tabular}{|c|c|c|c|c|c|}
\hline Kota & 2013 & 2014 & 2015 & 2016 & 2017 \\
\hline Padang & 60,31 & 69,19 & 82,83 & 89,76 & 103,27 \\
\hline Kontribusi & $15,75 \%$ & $13,37 \%$ & $17,64 \%$ & $16,72 \%$ & $15,87 \%$ \\
\hline
\end{tabular}

Sumber : BPS, 2017.

Berdasarkan data di atas kontribusi PDRB - ADHB industri pariwisata kota Padang setiap tahunnya mengalami fluktuasi dengan kontribusi rata-rata 15,87\%. Jumlah kunjungan jumlah wisatawan ke kota Padang tahun 2017 sebanyak 3.750 .000 orang, tahun 2016 sebanyak 3.628.299 orang, tahun 2015 sebanyak 3.298.454 orang, tahun 2014 sebanyak 3.199.392 orang dan tahun 2013 sebanyak 3.001 .306 orang (Disbudpar, 2017). Meskipun kota Padang terpilih menjadi salah satu dari tujuh destinasi wisata yang ada di Indonesia yaitu Padang, Bukittinggi, Yogyakarta, Bogor, Bandung, Solo dan Malang tapi jumlah wisatawan yang berkunjung tahun 2013 - 2017 jumlahnya berfluktuasi setiap tahun. Hal tersebut merupakan tantangan bagi pemerintah untuk terus meningkatkan keindahan dan kenyamanan kota Padang.

Dengan mengembangkan Community Tourism Development (CTD) pemerintah berpeluang menerima pajak dan beraneka ragam retribusi resmi dari kegiatan industri pariwisata yang bersifat mulisektoral seperti hotel, restoran, usaha wisata, atraksi wisata, usaha perjalanan wisata, profesional convention organizer dan lain-lain. Banyak wisatawan yang berkunjung ke kawasan wisata di kota Padang dan membelanjakan uangnya sehingga velocity of money cukup tinggi. Kedatangan wisatawan mancanegara maupun domestik akan meningkatkan PAD sesuai hasil penelitian (Rosa, 2018) karena konsumsi wisatawan cenderung 
Jurnal Manajemen dan Kewirausahaan, Volume 9, Nomor 3, September 2018

ISSN: $2086-5031$

E-ISSN 2615-3300

DOI 10.31317

akan meningkatkan output, barang dan

gaya hidup manusia sebagai bagian dari upah di sektor yang menjual barang maupun jasa kepada para wisatawan. Konsumsi wisatawan akan menciptakan permintaan barang dan jasa yang akan memberi value added kepada PDRB suatu daerah.

Jumlah hotel juga berpengaruh terhadap PDRB kota Padang karena hotel merupakan sektor paling dominan mendapatkan masukan dari konsumsi wisatawan. Jumlah hotel merupakan indikator produktivitas yang sering digunakan pada industri pariwisata. Di Kota Padang jumlah hotel bintang empat sebanyak 10 buah, bintang tiga sebanyak 11 buah, bintang dua sebanyak 13 buah dan bintang satu sebanyak 19 buah ditambah dengan beberapa buah hotel kelas melati. Meskipun jumlah hotel berbintang dan hotel kelas melati cukup banyak di kota Padang tapi tarif per kamarnya relatif tinggi dibandingkan dengan hotel lain yang ada di pulau Sumatera.

Industri pariwisata tidak terlepas dari jasa penyedia makanan dan minuman (restoran) dalam pembentukan PDRB. Restoran salah satu bidang usaha yang mendukung perkembangan industri pariwisata. Menurut (Hashim, 2011) restoran memiliki peran penting dalam aktivitas sosial mereka dengan berbagai restaurant atmosphere. Berbagai jenis makanan dan minuman (restoran) yang disediakan oleh pedagang di berbagai objek wisata kota Padang namun harga yang ditetapkan para pedagang terlalu tinggi sehingga membuat para wisatawan malas untuk berbelanja atau hanya satu kali saja datang berkunjung untuk wisata karena tidak ada standar harga barang yang dijual.

\section{B . Masalah Penelitian}

Masalah penelitian ini bagaimanakah pengaruh industri pariwisata terhadap PDRB kota Padang secara parsial dan simultan.

\section{Tujuan Penelitian}

Berdasarkan masalah penelitian di atas maka tujuan penelitian untuk mengetahui pengaruh industri pariwisata terhadap PDRB kota Padang secara parsial dan simultan.

\section{II . TINJAUAN TEORITIS}

\section{A . Produk Domestik Regional Bruto}

Produk Domestik Regional Bruto (PDRB) salah satu perangkat data ekonomi yang dapat digunakan untuk mengevaluasi kinerja pembangunan ekonomi suatu wilayah (propinsi maupun kabupaten/kota) diantaranya untuk melihat nilai nominal PDRB, struktur 
Jurnal Manajemen dan Kewirausahaan, Volume 9, Nomor 3, September 2018

ISSN: $2086-5031$

E-ISSN 2615-3300

DOI 10.31317

ekonomi, laju pertumbuhan ekonomi, PDRB per kapita dan sebagainya. PDRB menurut lapangan usaha terdiri atas pertanian, kehutanan dan perikanan, pertambangan dan penggalia, industri pengolahan, pengadaan listrik dan gas, pengadaan air, konstruksi, perdagangan besar dan eceran, transportasi dan pergudangan, penyediaan akomodasi, informasi dan komunikasi, jasa keuangan dan asuransi, real estate, jasa perusahaan, administrasi pemerintahan, jasa pendidikan, jasa kesehatan dan kegita sosial serta jasa lainnya.

Perangkat data PDRB dapat pula digunakan untuk kepentingan dan tujuan lain seperti sebagai dasar pengembangan model-model ekonomi dalam rangka menyusun formulasi kebijakan, velocity of money, financial deepening, penetapan pajak, kajian ekspor dan impor dan sebagainya. Menurut teori ekonomi makro penghitungan PDRB dapat dilakukan melalui pendekatan production approach, expenditure approach dan income approach. Ketiga pendekatan penghitungan tersebut secara teori akan menghasilkan angka PDRB yang sama (Sukirno, 2012).

\section{B . Konsep Pariwisata}

Pariwisata dikenal dengan istilah tourism berarti kepariwisataan. Menurut
Marpaung, (2012) pariwisata merupakan gabungan gejala atau hubungan yang timbul dari interaksi wisatawan, bisnis, pemerintah serta masyarakat tuan rumah dalam proses menarik dan melayani wisatawan serta penunjang lainnya. Pariwisata juga dapat diartikan sebagai perjalanan yang dilakukan berkali-kali dari satu tempat ke tempat lain (Yoeti, 2013). Perjalanan wisata yang dilakukan bukan merupakan pergerakan yang bersifat ulang alik sebagaimana definisi yang dinyatakan oleh (Gunn, 2015) pariwisata adalah seluruh perjalanan wisata meliputi daerah yang luas namun bukan termasuk dalam pergerakan ulang alik. Pariwisata dapat dilihat sebagai suatu bisnis yang berhubungan dengan penyediaan barang dan jasa bagi wisatawan menyangkut setiap pengeluaran oleh atau untuk wisatawan / pengunjung dalam perjalannya (Kusmayadi, 2011).

Menurut BPS, (2017) pariwisata adalah semua rangkaian kegiatan yang berhubungan dengan gerakan manusia yang melakukan perjalanan atau persinggahan sementara dari tempat tinggalnya kesuatu tempat atau beberapa tempat tujuan di luar lingkungan tempat tinggalnya yang didorong oleh beberapa keperluan atau motif tanpa maksud 
Jurnal Manajemen dan Kewirausahaan, Volume 9, Nomor 3, September 2018

ISSN: $2086-5031$

E-ISSN 2615-3300

DOI 10.31317

mencari nafkah. Berdasarkan UU RI No.

9 tahun 2009 pariwisata merupakan gejala yang berhubungan dengan wisata termasuk pengusahaan objek dan daya tarik wisata serta usaha yang terkait dengan bidang tersebut. Dalam hal ini pariwisata berarti suatu industri baru atau sektor yang kompleks dan mampu memberikan pertumbuhan ekonomi yang cepat dalam penyediaan lapangan kerja, peningkatan penghasilan, standar hidup dan multiplier effect yang besar bagi sektor produktivitas lainnya.

Wisatawan dalam melakukan perjalannya karena motivasi fisik, motivasi budaya, motivasi pribadi, motivasi status dan prestise. Motivasi fisik ditujukan untuk penyegaran fisik dan mental yang berhubungan dengan kegiatan olah raga, pertunjukan yang bersifat santai dan motivasi lainnya yang berhubungan dengan kesehatan. Motivasi budaya merupakan kegiatan untuk mengetahui daerah lainnya tentang makanan, minuman, music, kesenian, cerita rakyat, tari-tarian, lukisan dan agama. Motivasi pribadi merupakan keinginan untuk bertemu dengan orang lain, mengunjungi relasi, menghindari hal-hal rutin atau keluarga dan tetangga atau mencari persahabatan. Motivasi status dan prestise berhubungan dengan kegiatan bisnis, konvensi, studi, mengejar hobi dan pendidikan (Marpaung, 2012).

Dalam melakukan perencanaan pengembangan pariwisata perlu dilihat jenis-jenis pariwisata yang berpotensial dan berkemungkinan untuk dikembangkan sebagai daerah tujuan wisata. Menurut (Yoeti, 2013) jenis pariwisata ditentukan berdasarkan motif tujuan perjalanan wisata seperti wisata budaya, wisata perjalanan, wisata komersial, wisata maritim dan wisata karya.

\section{C . Komponen Pariwisata}

Perjalanan wisata akan dipengaruhi oleh berbagai komponen yang terdapat di daerah atau objek wisata dengan komponen penawaran dan permintaan pariwisata. Permintaan pariwisata adalah produk dan jasa yang ditawarkan kepada wisatawan berupa semua produk yang diperuntukkan bagi atau dikonsumsi oleh seseorang. Kegiatan wisata dilakukan melalui mekanisme pasar dimana produk dijual kepada wisatawan. Jasa adalah layanan yang diterima wisatawan saat mereka memanfaatkan produk tersebut dimana jasa sifatnya intangible bahkan seringkali tidak dirasakan, merupakan akumulasi waktu, ruang dan personal yang memungkinkan wisatawan dapat menggunakan produk wisata. 
Jurnal Manajemen dan Kewirausahaan, Volume 9, Nomor 3, September 2018

ISSN: $2086-5031$

E-ISSN 2615-3300

DOI 10.31317

Unsur penawaran wisata disebut triple $A$ 's terdiri dari atraksi, aksessibilitas dan amenitas. Atraksi merupakan objek yang bersifat intangible dan tangible yang dapat memberikan kenikmatan kepada wisatawan bersifat alamiah, budaya dan buatan manusia (Yoeti, 2013). Aksessibilitas mencakup semua infrastruktur transportasi yang menghubungkan wisatawan dari, ke dan selama di daerah tujuan wisata mulai dari darat, laut dan udara tidak hanya menyangkut aspek kuantitas tapi juga inklusif waktu, ketepatan waktu, kenyamanan dan keselamatan. Amenitas adalah infrastruktur yang sebenarnya tidak langsung terkait dengan pariwisata tapi sering menjadi bagian kebutuhan wisatawan seperti bank, money changer dan telekomunikasi. Semakin lengkap dan terintegrasinya ketiga unsur tersebut dalam produk wisata maka semakin kuat posisi penawaran dalam sistem kepariwisataan.

Menurut (Wahab, 2016) permintaan pariwisata adalah segala sesuatu yang berhubungan dengan jumlah wisatawan secara kuantitaif dimana permintaan pariwisata dapat dibagi menjadi permintaan potensial dan permintaan sebenarnya. Permintaan potensial adalah sejumlah orang yang secara potensial akan sanggup dan mampu dalam melakukan perjalanan wisata. Permintaan sebenarnya adalah sejumlah orang yang sebenarnya berkunjung pada daerah tujuan wisata artinya sejumlah wisatawan yang secara nyata sedang berkunjung pada daerah wisatawan. Permintaan pariwisata memiliki beberapa karakteristik seperti elastisitas, kepekaan, musim dan perluasan. Aspek permintaan pariwisata dipengaruhi oleh biaya, daerah tujuan, bentuk perjalanan, waktu dan lama berwisata dan akomodasi yang digunakan dimana semuanya ini menjadi bahan pertimbangan bagi wisatawan sebelum mengambil keputusan untuk melakukan perjalanan wisata.

\section{D . Dampak Industri Pariwisata}

Industri pariwisata merupakan serangkaian perusahaan yang satu sama lainnya terpisah, sangat beraneka ragam dalam skala, fungsi, lokasi dan bentuk organisasi namun mempunyai hubungan fungsional terpadu dalam menghasilkan berbagai barang atau jasa bagi kepentingan kebutuhan wisatawan dalam perjalanan keperluan lainnya. Perusahaan primer mengurus keperluan transportasi, akomodasi, makanan dan minuman untuk persiapan perjalanan sedangkan perusahaan sekunder memasok cendera mata dan barang lain keperluan 
Jurnal Manajemen dan Kewirausahaan, Volume 9, Nomor 3, September 2018

ISSN: $2086-5031$

E-ISSN 2615-3300

DOI 10.31317

wisatawan, menyediakan hiburan kegiatan asuransi serta jasa bank. Di samping itu terdapat juga perusahaan yang menyelenggarakan penggalakan wisata, biro iklan dan jasa konsultasi bagi perusahaan pariwisata lainnya. Menurut (Soekadidjo, 2016) industri pariwisata berdampak positif dan negatif bagi masyarakat dan pemerintah setempat dengan kategori dampaknya sebagai berikut :

1. Dampak ekonomi, memberikan multiplier effect dan pendapatan bagi suatu negara atau daerah yang mengembangkan pariwisata sebagai industri.

2. Dampak sosial ekonomi, meningkatkan interaksi sosial, mobilitas sosial ke tempat yang kegiatan pariwisatanya tinggi, meningkatnya pengetahuan masyarakat terhadap bidang-bidang lain seperti transportasi, akomodasi, bahasa, etnik dan gaya hidup.

3. Dampak lingkungan, dapat menimbulkan rasa peduli terhadap lingkungan pada masyarakat sekitar objek wisata seperti penataan taman yang terawat, melindungi punahnya tanaman langka sebagai ciri khas daerah karena dapat dijadikan sebagai objek wisata.
Adapun dampak negatif industri pariwisata adalah sebagai berikut :

1. Dampak ekonomi, tidak stabilnya ekonomi suatu negara atau daerah yang menjadikan industri pariwisata sebagai sektor unggulan dalam penerimaan Pendapatan Asli Daerah (PAD) karena sektor ini mudah dipengaruhi oleh ekonomi dan keamanan global. Selain itu juga terjadinya kebocoran yang dipengaruhi oleh letak geografis, struktur perekonomian dn ukuran negara.

1. Dampak sosial budaya, terjadinya kesenjangan sosial antara wisatawan dengan penduduk lokal, attitude dari wisatawan yang ditiru masyarakat sehingga dapat merubah nilai-nilai sosial yang ada di masyarakat mengakibatkan hilangnya identitas seni akibat mengikuti permintaan pasar.

2. Dampak lingkungan, terjadinya pencemaran udara, tanah, air dan kemacetan lalu lintas serta terjadinya alih fungsi lahan terutama pertanian akibat adanya pembangunan sarana dan 
Jurnal Manajemen dan Kewirausahaan, Volume 9, Nomor 3, September 2018

ISSN: $2086-5031$

E-ISSN 2615-3300

DOI 10.31317

prasarana pariwisata yang tidak pada tempatnya.

\section{E . Kerangka Pemikiran}

Kerangka pemikiran adalah diagram yang menjelaskan secara garis besar alur logika berjalannya sebuah penelitian. Kerangka pemikiran dibuat berdasarkan pertanyaan penelitian da mempresentasikan beberapa konsep serta hubungan diantara konsep tersebut (Umar, 2015). Komponen utama kerangka pemikiran yang dikembangkan adalah variabel bebas dan variabel terikat. Berdasarkan tinjauan teori di atas maka kerangka pemikiran penelitian dapat ditentukan sebagai berikut :

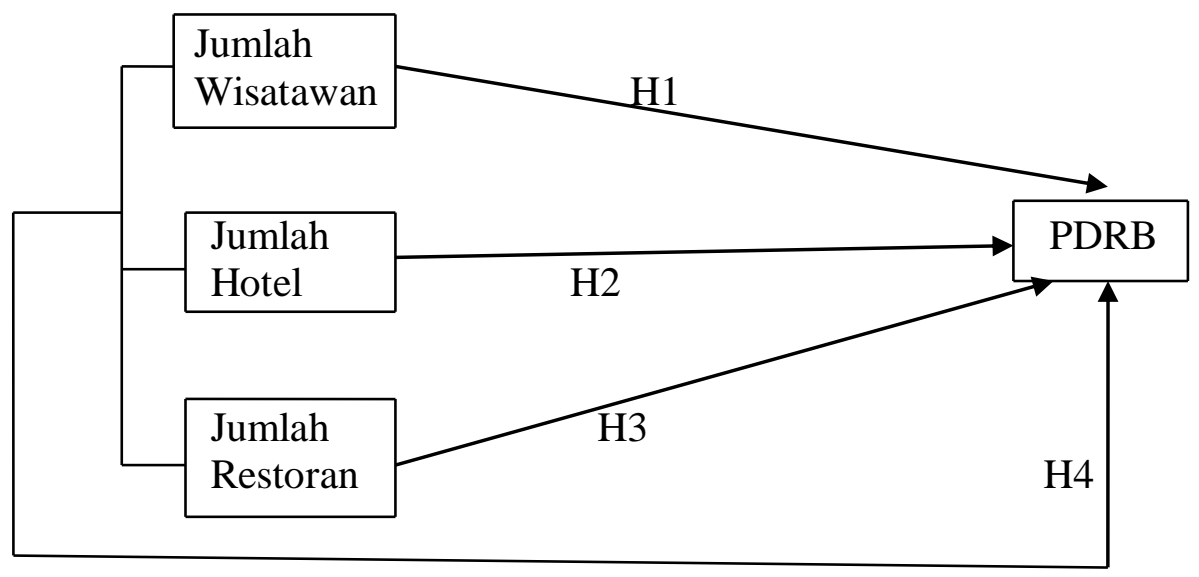

\section{E . Hipotesis Penelitian}

Hipotesis adalah jawaban sementara terhadap masalah yang bersifat praduga karena masih harus dibuktikan kebenarannya (Nazir, 2013). Hipotesis ilmiah mencoba memberikan jawaban sementara terhadap masalah yang akan diteliti. Hipotesis penelitian ini adalah sebagai berikut :

1. Diduga jumlah wisatawan berpengaruh signifikan terhadap PDRB kota Padang.
2. Diduga jumlah hotel berpengaruh signifikan terhadap PDRB kota Padang.

3. Diduga jumlah restoran berpengaruh signifikan terhadap PDRB kota Padang.

4. Diduga jumlah wisatawan, jumlah hotel dan jumlah restoran berpengaruh signifikan terhadap PDRB kota Padang.

\section{III . METODE PENELITIAN}

Jenis penelitian menggunakan pendekatan kuantitatif karena menurut (Sugiyono, 2011) pendekatan kuantitatif 
Jurnal Manajemen dan Kewirausahaan, Volume 9, Nomor 3, September 2018

ISSN: $2086-5031$

E-ISSN 2615-3300

DOI 10.31317

berlandaskan pada filsafat positivisme yang digunakan untuk meneliti populasi dan sampel tertentu, pengumpulan data menggunakan instrumen dan analisis data bersifat statistik. Data penelitian berupa data sekunder diperoleh dari Badan Pusat Statistik dan Dinas Kebudayaan dan Pariwisata Propinsi Sumatera Barat.

Data dikumpulkan menggunakan metode survey salah satu pendekatan penelitian yang umumnya digunakan untuk populasi yang cukup banyak (Nazir, 2013). Penelitian ini menggunakan data time series dengan beberapa keuntungannya menurut (Gujarati, 2012) antara lain dapat memberikan data yang lebih informatif, lebih variatif, mengurangi kolinieritas antar variabel, derajat kebebasan lebih banyak dan efisiensi. Teknik analisis data menggunakan analisis regresi non linier berganda dengan formula $\mathrm{Y}=\mathrm{a}+\mathrm{b} 1 \mathrm{X} 1+$ $\mathrm{b} 2 \mathrm{X} 2+\mathrm{b} 3 \mathrm{X} 3$ + e dimana $\mathrm{Y}=\mathrm{PDRB}, \mathrm{X} 1$ = jumlah wisatawan, $X 2=$ jumlah hotel, $\mathrm{X} 3=$ jumlah restoran, $\mathrm{a}=$ konstanta, b1,b2,b3 = koefisien regresi X1, X2, X3 dan $\mathrm{e}=$ error .

\section{IV • HASIL PENELITIAN DAN PEMBAHASAN}

\section{A . Gambaran Umum Variabel} Penelitian
Kota Padang merupakan kota besar di pantai Barat pulau Sumatera sebagai ibu kota propinsi Sumatera Barat. Luas wilayah kota Padang 694,96 km² dengan kondisi geografis berbatasan dengan laut dan dikelilingi perbukitan dengan ketinggian mencapai 1.853 mdpl. Menurut (BPS, 2017) jumlah penduduk kota Padang 902.413 jiwa dan kota Padang merupakan kota inti dari pengembangan wilayah metropolitan Palapa. Jumlah objek wisata di kota Padang dibedakan menurut jenisnya seperti wisata kuliner sebanyak 26 buah, wisata belanja sebanyak 41 buah, wisata budaya sebanyak 79 buah, wisata sejarah, sebanyak 1 buah, wisata bahari sebanyak 32 buah dan wisata alam sebanyak 9 buah (Disbudpar, 2017).

Kota Padang terkenal dengan legenda Sitti Nurbaya dan Malin Kundang saat ini sedang berbenah ke arah pembangunan kepariwisataan. Kota Padang memiliki sebuah Museum Adityawarman yang memiliki gaya arsitektur Rumah Gadang yang di halamannya terdapat dua buah lumbung padi. Museum ini mengkhususkan diri pada sejarah dan budaya suku Minangkabau, suku Mentawai dan suku Nias serta memiliki 6.000 koleksi buku. 
Jurnal Manajemen dan Kewirausahaan, Volume 9, Nomor 3, September 2018

ISSN: $2086-5031$

E-ISSN 2615-3300

DOI 10.31317

Di pelabuhan Muara banyak dijumpai bangunan peninggalan zaman Belanda dan beberapanya ditetapkan pemerintah sebagai tempat cagar budaya diantaranya Masjid Muhammadan dan Klenteng Kwan Im. Dari Batang Arau terdapat jembatan Sitti Nurbaya yang menghubungkan sebuah kawasan Bukit dengan nama Gunung Padang dimana dahulunya tempat pemukiman etnis Nias di kota Padang. Di pelabuhan Teluk Bayur terdapat beberapa kawasan wisata seperti pantai Air Manis tempat batu Malin Kundang, pantai Caroline dan pantai Bungus serta sebuah resort wisata kelas hotel bintang tiga yang terletak di pulau Sikuai. Kota Padang juga mempunyai beberapa buah pulau kecil dengan hamparan pasir putih yang jernih seperti pulau Swarnadwipa, pulau Pagang, pulau Pasumpahan dan pulau Sirandah.

Sebagai salah satu destinasi MICE (Meeeting, Incentive, Convention and Exhibition) terkemuka di Indonesia kota Padang memiliki banyak hotel berbagai kelas dan fasilitas baik hotel berbintang maupun hotel melati. Hotel bintang empat seperti The Axana Hotel, Grand Inna Padang, Grand Zuri Hotel, dan lainnya. Hotel bintang seperti Hotel Airy Padang, The Aliga Hotel, Hotel d'Ox Village, Daima Hotel, dan lainnya. Hotel bintang dua seperti Amaris Hotel, Bunda Hotel dan lainnya. Hotel bintang satu seperti Hotel Alifa Syariah, Hotel Sriwijaya, Hotel Femina dan lainnya.

Kota Padang juga terkenal akan masakan yang populer sampai ke mancanegara seperti rendang, ayam pop, gulai itik cabe hijau, nasi kapau dan sate Padang. Restoran Padang banyak terdapat di seluruh kota besar di Indonesia. Dalam mendorong pariwisata kota Padang, pemerintah menggelar festival rendang pertama kalinya tahun 2011 setelah sebelumnya rendang dinobatkan oleh CNN International sebagai hidangan peringkat pertama dalam daftar World's 50 Most Delicious Foods. Pada tahun yang sama pemerintah kota juga menyelenggarakan festival Sitti Nurbaya, pergelaran tahunan yang mengangkat adat dan tradisi Minangkabau.

\section{B . Hasil dan Pembahasan Penelitian}

Hasil analisis regresi non linier berganda dengan SPSS pada tingkat signifikansi $(\alpha)$ $=5 \%$ didapat persamaannya sebagai berikut :

$$
\operatorname{Ln} \mathrm{Y}=3.418+0.058 \operatorname{Ln} \mathrm{X} 1+0.103 \operatorname{Ln} \mathrm{X} 2+0.259 \operatorname{Ln} \mathrm{X} 3+\mathrm{e}
$$

$$
\text { (3.317) (2.134) (3.168) } \quad \text { t hitung }=2.021
$$


Jurnal Manajemen dan Kewirausahaan, Volume 9, Nomor 3, September 2018

ISSN: $2086-5031$

E-ISSN 2615-3300

DOI 10.31317

$\mathrm{F}$ hitung $=5.889$ dan $\mathrm{F}$ tabel $=2.61$

$\mathrm{R}=0.749 \quad \mathrm{R}^{2}=0.614$ dan Adjusted R Square 0.602

Interpretasi persamaan di atas adalah sebagai berikut :

- $\mathrm{a}=3.418$ berarti jika jumlah wisatawan, jumlah hotel dan jumlah restoran tidak ada maka PDRB kota Padang tetap sebesar $3.418 \%$.

- $\mathrm{b} 1=0.058$ berarti jika jumlah jumlah wisatawan meningkat $1 \%$ maka PDRB kota Padang akan meningkat sebesar $0.058 \%$ dengan asumsi ceteris paribus.

- $\mathrm{b} 2=0.103$ berarti jika jumlah hotel meningkat $1 \%$ maka PDRB kota Padang akan meningkat sebesar $0.103 \%$ dengan asumsi ceteris paribus.

- $\mathrm{b} 3=0.259$ berarti jika jumlah restoran meningkat $1 \%$ maka PDRB kota Padang akan meningkat sebesar $0.259 \%$ dengan asumsi ceteris paribus.

Berdasarkan persamaan regresi non linier berganda di atas ternyata jumlah restoran lebih besar pengaruhnya dibandingkan dengan jumlah wisatawan dan jumlah hotel. Komponen terpenting yang harus diperhatikan dalam kepariwisataan adalah tersedianya restoran (rumah makan) yang memadai bagi wisatawan. Jenis rumah makan yang cocok, bentuk dan cara pelayanan serta jenis makanan yang akan disajikan hendaknya memperhatikan selera dan kebiasaan para wisatawan. Hal tersebut harus menjadi pertimbangan bagi pengelola paket wisata termasuk para pramu wisata. Dalam penyajian makanan perlu diperhatikan penyajian makanan apakah international style, fast food atau self service.

Pengeluaran untuk makan dan minum para wisatawan banyak tergantung pada disposable income masing-masing keluarga dalam masyarakat. Bagi wisatawan yang makan di luar hotel perlu peningkatan pelayanan penyediaan makanan yang lebih cepat (to serve fast foods). Semua ini membuat kita harus dapat menciptakan sistem penyediaan dan pelayanan restoran dimasa-masa yang akan datang. Karena itu perencanaan sebuah restoran selalu akan disesuaikan dengan keadaan yang selalu berubah seperti pola konsumsi, life style dan corak perekonomian dunia.

Beberapa dasar pertimbangan yang perlu diperhitungkan dalam membuka usaha sebuah restoran terutama yang 
Jurnal Manajemen dan Kewirausahaan, Volume 9, Nomor 3, September 2018

ISSN: $2086-5031$

E-ISSN 2615-3300

DOI 10.31317

berhubungan dengan kebutuhan wisatawan mancanegara dan domestik seperti lokasi, ukuran restoran, pasar yang akan dimasuki, jenis menu serta cara dan macam pelayanan yang dapat diberikan. Perencanaan menu dalam mengembangkan usaha restoran perlu memperhatikan operating philosophy,market, concept, location dan atmosphere. Hal ini menunjukkan bahwa restaurant atmosphere merupakan bagian penting dari sebuah usaha restoran yang tidak dapat dihilangkan karena restaurant atmosphere merupakan efek seketika yang diberikan oleh sebuah restoran kepada para pelanggannya baik disadari atau tidak.

\section{Uji Parsial (Uji t)}

Uji parsial (uji t) bertujuan untuk menguji hipotesis apakah masing-masing variabel bebas berpengaruh signifikan terhadap variabel terikat. Berdasarkan hasil persamaan regresi linier berganda didapat $\mathrm{t}$ hitung untuk jumlah wisatawan (3.317), jumlah hotel (2.134) dan jumlah restoran (3.168). Bila dibandingkan $\mathrm{t}$ hitung dengan $t$ tabel untuk masing-masing variabel bebas maka jumlah wisatawan berpengaruh positif signifikan terhadap PDRB kota Padang karena $\mathrm{t}$ hitung > t tabel $(3.317>2.021)$, jumlah hotel berpengaruh positif signifikan terhadap PDRB kota Padang karena t hitung > t tabel $(2.134>2.021)$ dan jumlah restoran berpengaruh positif signifikan terhadap PDRB kota Padang karena $\mathrm{t}$ hitung $>\mathrm{t}$ tabel $(3.168>2.021)$. Berarti hipotesis penelitian diterima jumlah wisatawan, jumlah hotel dan jumlah restoran berpengaruh positif signifikan terhadap PDRB kota Padang secara parsial.

\section{Uji Simultan (Uji F)}

Uji simultan (uji F) bertujuan untuk menguji hipotesis apakah semua variabel bebas berpengaruh terhadap variabel terikat. Dengan membandingkan F hitung dengan $\mathrm{F}$ tabel $(5.889>2.61)$ maka jumlah wisatawan, jumlah hotel dan jumlah restoran berpengaruh positif signifikan terhadap PDRB kota Padang secara simultan sehingga hipotesis penelitian diterima.

\section{Adjusted R Square}

Jumlah wisatawan, jumlah hotel dan jumlah restoran berhubungan kuat dengan PDRB kota Padang $(\mathrm{R}=0.749)$ sedangkan nilai Adjusted $R$ Square = 0.602 berarti jumlah wisatawan, jumlah hotel dan jumlah restoran mampu menjelaskan PDRB kota Padang sebesar $60,2 \%$ sedangkan sisanya $39,8 \%$ dijelaskan oleh variabel lain yang tidak termasuk dalam model penelitian ini. 
Jurnal Manajemen dan Kewirausahaan, Volume 9, Nomor 3, September 2018

ISSN: $2086-5031$

E-ISSN 2615-3300

DOI 10.31317

\section{V . SIMPULAN DAN SARAN}

\subsection{Kesimpulan}

Berdasarkan hasil dan pembahasan penelitian didapat kesimpulan penelitian sebagai berikut :

1. Jumlah wisatawan berpengaruh positif signifikan terhadap PDRB kota

Padang karena $\mathrm{t}$ hitung $>\mathrm{t}$ tabel $(3.317>2.021)$.

2. Jumlah hotel berpengaruh positif signifikan terhadap PDRB kota Padang karena

$\mathrm{t}$ hitung > t tabel $(2.134>2.021)$.

3. Jumlah restoran berpengaruh positif signifikan terhadap PDRB kota Padang karena $\mathrm{t}$ hitung $>\mathrm{t}$ tabel $(3.168>2.021)$.

4. Jumlah wisatawan, jumlah hotel dan jumlah restoran berpengaruh positif signifikan terhadap PDRB kota Padang karena $\mathrm{F}$ hitung $>\mathrm{F}$ tabel $(5.889>2.61)$.

\subsection{Saran}

Beberapa saran yang dapat diberikan sesuai hasil dan pembahasan penelitian di atas adalah sebagai berikut :

1. Perlu melakukan penataan dan pembenahan berbagai objek wisata dan akses transportasi agar industri pariwisata di kota Padang dapat lebih berkembang sehingga akan menambah jumlah wisatawan mancanegara dan domestik untuk berkunjung.

2. Perlu ada aturan yang jelas dalam bentuk Peraturan Daerah yang mengatur tentang tarif parkir di berbagai objek wisata yang ada di kota Padang karena selama ini masih ada tarif parkir tidak sesuai ketentuan pemerintah.

3. Perlu ada aturan yang tegas dalam bentuk Peraturan Daerah yang mengatur tentang tarif makanan dan minuman di berbagai objek wisata yang ada di kota Padang karena selama pedagang menetapkan harga makanan tidak sesuai dengan harga pasar.

4. Pelayanan perlu ditingkatkan berhubungan dengan pelayanan parkir, pelayanan hotel dan pelayanan makanan, minuman (restoran) agar wisatawan merasa puas selama melakukan kunjungan wisata di kota Padang.

\section{DAFTAR PUSTAKA}

Affandi, Ahmad. 2012. Pengaruh Industri Pengolahan, Perdagangan, Hotel, Restoran dan Pertanian Terhadap PDRB Kabupaten Mojokerto. Jurnal Ekonomi Pembangunan Vol.14 No. 1.

Antari, Ni Luh. 2013. Peran Industri Pawisata Terhadap Penerimaan Pendapatan Asli Daerah Kabupaten Gianyar. Jurnal Perhotelan dan Pariwisata. Vol.3 No. 1. 
Badan Pusat Statistik. 2017. Sumatera Barat Dalam Angka. Padang.

Colombijn, Freek. 2006. Paco-Paco Kota Padang : Sejarah Sebuah Kota Di Indonesia Pada Abad Ke 20 dan Penggunaan Ruang Kota. Penerbit Ombak. Yogyakarta.

Dinas Kebudayaan dan Pariwisata Propinsi Sumatera Barat. 2017. Pariwisata Dalam Angka. Padang.

Gujarati. 2012. Dasar-Dasar Ekonometrika Edisi 5 Buku 2. Salemba Empat. Jakarta.

Gunn. 2015. Faktor - Faktor yang Mempengaruhi Minat Wisatawan Mengunjungi Objek Wisata Kawah Ijo. Jurnal Ilmu Ekonomi Vol.1 No.1.

Hashim, F.A. 2011. Retaurant's Atmosphere Elements : Whats the Customer Wants. Journal of Asian Behavioral Studies. Vol. 1 No.2.

Kusmayadi. 2011. Faktor-Faktor yang Mempengaruhi Kunjungan Wisata Di Taman Nasional Way Kamba Propinsi Lampung. Artikel Pariwisata.

Marpaung, Happy. 2012. Pengetahuan Kepariwisataan. Alfabeta. Bandung.

Nazir. 2013. Metode Penelitian. Ghalia Indonesia. Jakarta.

Rosa, Yenni Del. 2018. Pengaruh Kontribusi Objek Wisata Pantai Gandoriah

Pariaman Terhadap Pendapatan Asli Daerah Kabupaten Pariaman. Jurnal Menara Ekonomi. Volume IV No. 2.

Soekadidjo. 2016. Anatomi Pariwisata. PT Gramedia Pustaka Utama. Jakarta.

Sugiyono. 2011. Metode Penelitian Kuantitatif dan Kualitatif. Alfabeta. Bandung.

Sukirno, Sadono. 2012. Pengantar Ekonomi Makro. PT Rajawali. Jakarta.

UNWTO. 2013. Facts and Figure Education Page. Retrieved November 08, 2013, from World Tourism Organization : http://www22.unwto.org/?q=facts/wtb.ht $\underline{\mathrm{ml}}$.

Umar, Husein. 2015. Metode Riset Bisnis. PT Raja Grafindo Persada. Jakarta.

Undang-Undang RI No. 9 Tahun 2009. Tentang Kepariwisataan. Jakarta.

Wahab, Salah. 2016. Manajemen Kepariwisataan. PT Pranya Paramita. Jakarta.

Yoeti. 2013. Perencanaan Strategis Pemasaran Daerah Tujuan Wisata. PT Pradnya Paramita. Jakarta. 